\title{
The social provision of healthcare to migrants in the US and in China
}

\author{
Van C. Tran ${ }^{1} \cdot$ Katharine M. Donato $^{2}$
}

Received: 5 January 2018 / Accepted: 27 February 2018 / Published online: 25 June 2018

(C) Springer Nature Singapore Pte Ltd. 2018

\begin{abstract}
This article develops a comparative analysis of healthcare provision to migrants in the US and in China. It proceeds in three parts. First, we begin by describing the growth of the unauthorized population and trace the evolution of social provision of healthcare to immigrants, highlighting the restrictive nature of federal social provisions and greater autonomy of state and local governments in redefining eligibility criteria in the US. Second, we examine the impact of legal status on healthcare access and utilization among Mexicans, using original data from the 2007 Hispanic Healthcare Survey and the Mexican Migration Project. We find that unauthorized immigrants report the lowest level of healthcare access and utilization. Third, we then outline a China-US comparative agenda, pointing to similarities between the two migrant flows. In China, recent developments of healthcare coverage for both rural and urban populations have increased access to healthcare, but rural-to-urban migrants still report many barriers in receiving care and are often left out of this growing safety net. We then close with a discussion of lessons learned from the US experience and remaining questions for future comparative research.
\end{abstract}

Keywords Unauthorized migrants · Rural-to-urban migrants · Social provision · Healthcare access · Comparative research $\cdot$ US and China

We would like to thank Jennifer Holdaway, Zhenzhen Zheng and two anonymous reviewers for helpful feedback on previous drafts.

Van C. Tran

vantran@columbia.edu

1 Department of Sociology, Columbia University, New York, NY, USA

2 School of Foreign Service, Georgetown University, Washington, DC, USA 


\section{Introduction}

One key achievement in President Obama's first term was the passage of comprehensive healthcare reform (also known as the Patient Protection and Affordable Care Act or Obamacare) in 2010, which significantly expanded healthcare coverage to the uninsured. Among concerns raised in the public debate on healthcare reform was whether the bill would provide healthcare to unauthorized immigrants. One memorable moment was when Representative Joe Wilson from South Carolina heckled the president during a joint session of Congress. As President Obama refuted the idea that the reform would benefit the unauthorized, Wilson shouted "you lie" to the president — an incident that went viral on social media. In some ways, this moment not only captured the contentious and heated debate about the social provision of healthcare, but it also highlighted how federal and local policy decisions affect the daily lives of US immigrants.

This paper provides a comparative analysis of healthcare access to unauthorized migrants in the US and rural-to-urban migrants in China. The paper will proceed in three parts. Drawing on recent studies about immigrant incorporation, social protection and public health, the first part provides an overview of the unauthorized population, the evolution of the institutional and policy contexts related to healthcare access, and the public debate on healthcare access for immigrants. The second part presents original results from our analysis of data from the Hispanic Healthcare Survey and the Mexican Migration Project to examine how legal status shapes healthcare access among Mexicans, the group that comprises the majority of the unauthorized population. In the third part, we establish similarities between the Mexico-US migration flow and the rural-to-urban migration in China. We discuss the rapidly changing landscape of healthcare provision in China and the implications of our analysis of healthcare provision to immigrants in the US for migrants' healthcare in urban China. We then end with suggestions for future comparative work.

\section{The policy context: provision of healthcare to unauthorized immigrants in the US}

This section begins with an overview of the unauthorized population in the US We then outline the evolution of policies and practices related to social protection for immigrants. We ask how legal status shapes healthcare provision in the US and discuss the nature of citizenship and inclusionary criteria in the US. We then ask how this might apply to China, where questions of legal status are of a different nature because rural-to-urban migrants are all Chinese citizens.

\subsection{The unauthorized population in the US}

A word on terminology before we proceed. We will use the term unauthorized to refer to migrants who reside in the US without legal authorization from the 
US government. We chose unauthorized instead of illegal or undocumented for three reasons. First, the term illegal denotes potential criminality and is linked to recent policy developments to criminalize this population. Second, the term undocumented is not entirely accurate because many unauthorized immigrants have some forms of documentation or identification card, either issued by their home country or by the US government such as a driver's license or a municipal ID card. Third, one key goal of this article is to compare healthcare provision in the US and China, unauthorized comes closer to the lived reality of both (im)migrant populations in the two national contexts in our analysis.

Dramatic growth of the unauthorized population over the last two decades has dominated discussions of immigration policy to the forefront of political agendas. However, beyond politics and media headlines, the increasing presence of the unauthorized population has direct impacts on local communities. The size and diversity of the unauthorized population have also increased over time (Donato and Armenta 2011). As a response to this shift, there is more diversity in the range of local policy reactions than in the past, from welcoming and neutral tolerance to hostile apprehension and deportation (Joseph and Marrow 2017; Armenta 2017; Hopkins 2010).

The size of the unauthorized population in the US has grown rapidly since 1986, the last time when the United States offered an amnesty program (discussed in more detail below). There were only 3.5 million unauthorized immigrants in the US in 1990. This population grew to 8.4 million in 2000 and peaked at 12.2 million in 2007 before declining and stabilizing at 11 million since 2010 (Krogstad et al. 2017). This population is highly concentrated. Six states including California, Texas, Florida, New York, New Jersey and Illinois account for 59\% of the total number unauthorized immigrants (Krogstad et al. 2017). Passel and Cohn (2011: ii) also estimate that nearly half of unauthorized immigrant households were couples with children and $60 \%$ were of Mexican descent. Furthermore, about two-thirds reported having lived in the US for over a decade in 2014 compared to only $14 \%$ who were in the country for less than 5 years (Krogstad et al. 2017).

This growth in the unauthorized population has occurred as immigration policy became increasingly more restrictive over time, which carries important consequences for the health and well-being of unauthorized migrants. For example, Donato and Armenta (2011) emphasize the relationship between immigration laws and unauthorized status, pointing out that nation-states increasingly approach the unauthorized population with "restriction, criminalization and deportation" (p. 534). Local responses to the unauthorized have also changed, as US states and local governments have passed different forms of legislation that target the unauthorized and increasingly limit immigrant access to social services and healthcare benefits (Hopkins 2010). Furthermore, federal government policies and guidelines about the unauthorized population have become decoupled from the actual practices of local police and bureaucrats on the frontline of dealing with the unauthorized, with mostly negative impacts on this population (Joseph and Marrow 2017; Marrow 2012; Donato and Armenta 2011; Donato and Rodriguez 2014). 
Table 1 Key programs and their impacts on immigrants' access to healthcare and social benefits in the US (1965-2010)

Program description Impact on the immigrant population

Medicaid (1965)

Medical coverage for the poor: children, parents, disabled and elderly

Coverage to poor legal immigrants and their children

Medicare (1965)

Medical coverage for the elderly

Coverage to legal immigrants if they have worked for 10 years

Immigration Reform and Control Act (1986)

Amnesty program for unauthorized immigrants

Providing legal status and access to social and health benefits

Emergency Medical Treatment and Active Labor Act (1986)

Requires hospital emergency rooms to assess and Coverage for patients in emergency room regardless treat all patients of status

Disproportionate Share Hospital Program (1986)

Reimburse hospitals with a disproportionate share of Medicaid and uninsured patients

Coverage for low-income immigrants not eligible for Medicaid

Personal Responsibility and Work Opportunity Reconciliation Act (1996)

Welfare reform and changes in Medicaid and food stamps eligibility for all legal and unauthorized immigrants

Coverage for legal immigrants after a five-year wait period; no coverage for unauthorized immigrants

Children's Health Insurance Program (1997)

Expansion of medical coverage for all uninsured children

Coverage for children of legal immigrants; no coverage for children of unauthorized immigrants

Patient Protection and Affordable Care Act (2010)

Expansion of medical coverage for all uninsured Americans

Coverage for uninsured legal immigrants; no coverage for unauthorized immigrants

Source: Adapted from Warner (2012, Table 1, pp. 43-44)

\subsection{The evolution of social provision of healthcare}

In what follows, we offer a brief history of the evolution of healthcare policy towards migrants in the US since 1965. Healthcare access has moved to the forefront of policy debates because of the rising cost of providing care. Between 1970 and 2008 , total spending on medical care grew from $\$ 74.9$ billion to $\$ 2.3$ trillion, or 7.2 and $16.2 \%$ of the US gross national product, respectively (Hartman et al. 2010: 147). Drastically higher healthcare costs have also led to shifts in healthcare coverage and redefined eligibility criteria for both legal and unauthorized immigrants. Table 1 describes eight key programs and their impacts on immigrants' access to healthcare and social benefits since 1965; it begins with Medicaid and Medicare, which initially benefited legal immigrants. Over the last five decades, there have been three key turning points in the policy context: the 1986 Immigration Reform and Control Act (IRCA), the 1996 Personal Responsibility and Work Opportunity Reconciliation Act (PRWORA), and the 2010 Patient Protection and Affordable Care Act (ACA). 
We briefly outline these changes and discuss their consequences, especially for the provision of healthcare coverage for the unauthorized.

We begin with IRCA (passed in 1986) which included an amnesty program that granted permanent legal status to about 3.1 million immigrants, approximately 2 million from Mexico, 5 years after their initial application in 1987. This legislation had wide-ranging and sweeping impacts. If they met the age and income criteria for government health programs, such as Medicare and Medicaid, individuals who were able to regularize their status via IRCA's amnesty became able to access this healthcare coverage. In contrast, one decade later, the pendulum swung the other way toward more restrictive prescriptions after Congress passed and President Clinton signed PRWORA into law. The legislation (also known as welfare reform) introduced further restrictions for benefits eligibility. Unauthorized immigrants continued to be ineligible for government health benefits, except for emergency medical services funded through Medicaid and immunizations of communicable diseases, ${ }^{1}$ and only legal permanent residents were deemed eligible for public benefits (Amuedo-Dorantes et al. 2013). This legislation also implemented a 5-year waiting period for authorized migrants who arrived after 1996 to access benefits. Thus, for the first time, naturalized citizens and other legal immigrants without private healthcare insurance were restricted from public health benefits.

PRWORA marked a key turning point in the provision of services to immigrants. Among public service programs, unauthorized immigrants are not eligible for Medicaid, Medicare, Social Security Income Assistance, Children's Health Insurance Program (CHIP), ${ }^{2}$ although they are eligible for Supplemental Nutrition Assistance Program (SNAP or formerly known as food stamps) and Supplemental Nutrition Program for Women, Infants, and Children (WIC).

Table 2 summarizes immigrant status and eligibility in four key social safety programs: SNAP, TANF, Medicaid and CHIP. Although immigrant children and pregnant women are largely eligible for these programs, most immigrants are either eligible or not, with a clear line being drawn between pre- and post-enactment PRWORA (i.e. pre-and post-1996 by year of US arrival). Legal permanent residents, refugees and asylees, persons paroled into the United States for at least 1 year, persons granted withholding of deportation or removal, battered spouses and children, Cuban and Haitian entrants, and victims of severe human trafficking were eligible to receive benefits. Non-eligible immigrants included foreign-born persons not included in the qualified group, such as those with temporary protected status, asylum applicants, other lawfully present immigrants (such as students and tourists), and unauthorized immigrants. In other words, the provision of assistance became increasingly more restrictive, even for eligible immigrants.

Beyond these federal programs, there is substantial variation at state and local levels. Since 2009, states have selectively expanded their Medicaid and CHIP programs to provide coverage for pregnant women and children who have previously

\footnotetext{
1 The Emergency Medical Treatment and Active Labor Act, passed in 1986, required hospitals to provide medical care to all patients in the emergency room, irrespective of legal status.

2 This is also known as the State Children Health Insurance Program (SCHIP).
} 


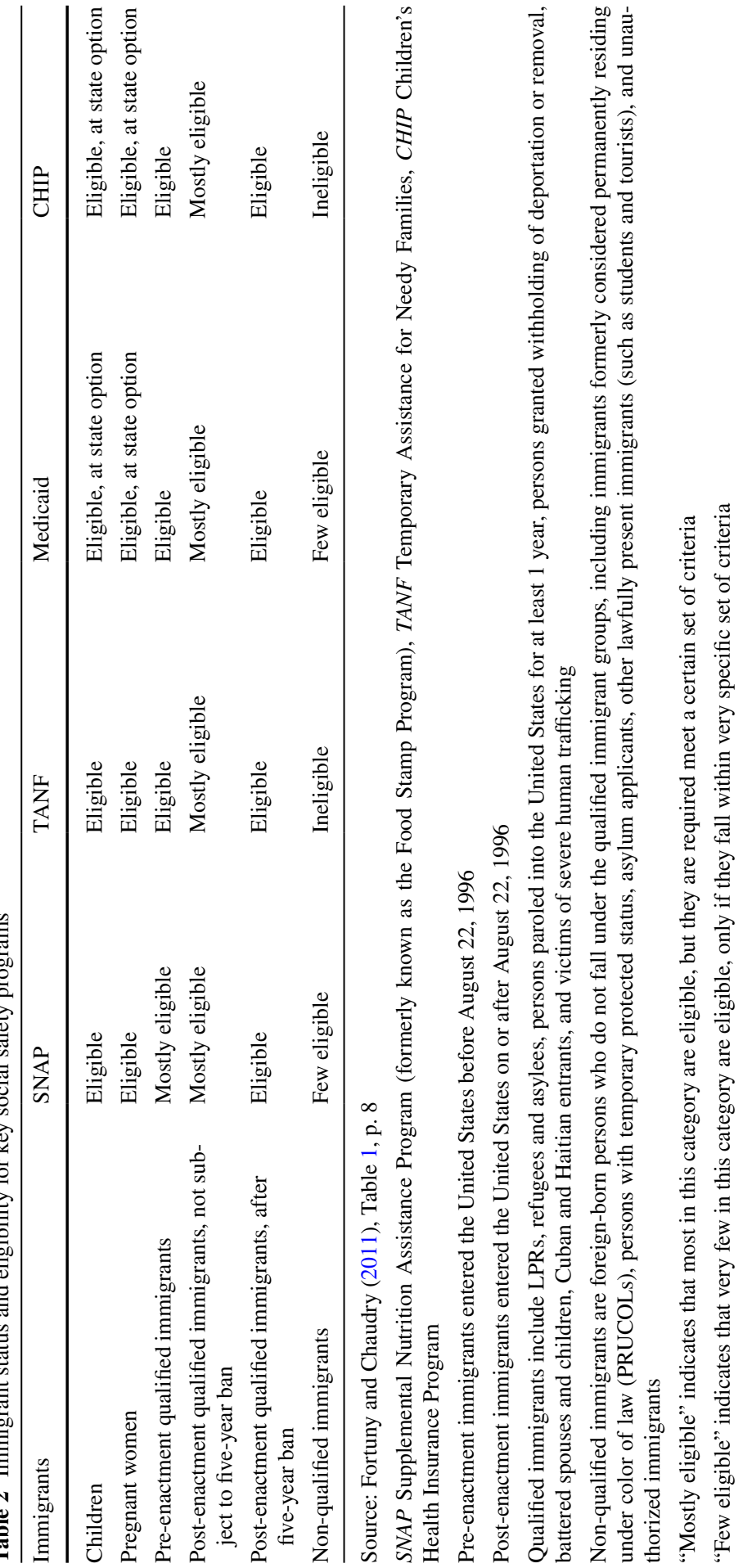


been banned from the program but benefits are limited only to legal immigrants. Table 3 describes eligibility for food assistance, cash assistance, and healthcare for immigrants by state and reveals substantial variability. As of 2010, only seven states provide food assistance to eligible immigrants, including California, and 22 states provide cash assistance including the top three states with the largest shares of immigrants (i.e. California, New York, and New Jersey). With respect to healthcare coverage, the situation is more nuanced; 15 states provide coverage to eligible immigrants and 17 states provide coverage to non-eligible immigrants. For example, unauthorized immigrants are eligible for Medicaid through the Medi-Cal program in California, but benefits are limited to "emergency (including labor and delivery), prenatal, and long-term care" (Goldman et al. 2005: 1645). In contrast, the Healthy Families program (California's main SCHIP program) pays for coverage of more than 1 million formerly uninsured children, but it does not provide benefits to unauthorized children or legal immigrants living in the United States for less than 5 years.

Table 4 shows significant state variation in the public vs. private sources of healthcare coverage. In 2012, about half of the total US population received healthcare coverage through their employers and one-third relied on a public program such as Medicare or Medicaid. The rest either purchased health insurance through the private market or remained uninsured. ${ }^{3}$ Table 4 shows rates of employer-based health insurance ranging from 38\% in New Mexico to 59\% in New Hampshire, and rates of publicly insured populations ranging from a low of $21 \%$ in Utah to a high of $40 \%$ in Vermont.

Beyond Medicaid and Medicare, many low-income and uninsured individuals, including many unauthorized immigrants, increasingly receive healthcare through the Federally Qualified Health Centers (FQHCs). The FQHC initiative, established under former President George W. Bush, was designed to provide affordable healthcare to marginalized populations. FQHCs receive federal grants under Section 330 of the Public Health Service Act (PHS) to serve an underserved area or population, provide a sliding fee structure, and offer comprehensive healthcare services. The last column of Table 4 shows significant state-level variation in the number of FQHCs, with California reporting 121 centers, the highest among all states. More generally, the top five immigrant-receiving states reported the most FQHCs, highlighting their importance as part of the immigrant safety net. For example, by 2006, the FQHC program had significantly expanded, increasing to 1200 nationwide and providing healthcare for 15 million patients (Portes et al. 2012). In 2007, they served one in nine Hispanics, one in eight uninsured, and one in seven US residents living below the poverty line (US Bureau of Primary Care 2008). In fact, FQHCs may be considered a national safety net for healthcare; they offer crucial healthcare access to vulnerable populations and represent "the cornerstone of an improved medical system" (Searles 2012: 145). One provision of the 2010 ACA expanded the program, reserving $\$ 11$ billion for

\footnotetext{
3 The category of those uninsured has changed since the implementation of the Patient Protection and Affordable Care Act (ACA), which seeks to provide coverage for those uninsured.
} 
Table 3 Types of social provision to immigrants by state in 2010

\begin{tabular}{|c|c|c|c|c|}
\hline & Food assistance & Cash assistance & $\begin{array}{l}\text { Healthcare cover- } \\
\text { age }\end{array}$ & Healthcare coverage \\
\hline & $\begin{array}{l}\text { Qualified immi- } \\
\text { grants }\end{array}$ & $\begin{array}{l}\text { Qualified immi- } \\
\text { grants }\end{array}$ & $\begin{array}{l}\text { Qualified immi- } \\
\text { grants }\end{array}$ & $\begin{array}{l}\text { Non-qualified } \\
\text { immigrants }\end{array}$ \\
\hline \multicolumn{5}{|l|}{ Alabama } \\
\hline Alaska & & & Yes & Yes \\
\hline Arizona & & Yes & & \\
\hline \multicolumn{5}{|l|}{ Arkansas } \\
\hline California & Yes & Yes & Yes & Yes \\
\hline \multicolumn{5}{|l|}{ Colorado } \\
\hline Connecticut & Yes & Yes & & \\
\hline Delaware & & & Yes & Yes \\
\hline $\begin{array}{l}\text { District of Colum- } \\
\text { bia }\end{array}$ & & & Yes & Yes \\
\hline Florida & & & & Yes \\
\hline Georgia & & Yes & & \\
\hline Hawaii & & Yes & Yes & Yes \\
\hline \multicolumn{5}{|l|}{ Idaho } \\
\hline Illinois & & Yes & Yes & Yes \\
\hline \multicolumn{5}{|l|}{ Indiana } \\
\hline Iowa & & Yes & & \\
\hline \multicolumn{5}{|l|}{ Kansas } \\
\hline \multicolumn{5}{|l|}{ Kentucky } \\
\hline \multicolumn{5}{|l|}{ Louisiana } \\
\hline Maine & Yes & Yes & & \\
\hline Maryland & & Yes & & \\
\hline Massachusetts & & & Yes & Yes \\
\hline \multicolumn{5}{|l|}{ Michigan } \\
\hline Minnesota & Yes & Yes & Yes & Yes \\
\hline \multicolumn{5}{|l|}{ Mississippi } \\
\hline \multicolumn{5}{|l|}{ Missouri } \\
\hline \multicolumn{5}{|l|}{ Montana } \\
\hline Nebraska & Yes & Yes & Yes & \\
\hline Nevada & & Yes & & \\
\hline \multicolumn{5}{|l|}{ New Hampshire } \\
\hline New Jersey & & Yes & Yes & Yes \\
\hline New Mexico & & Yes & Yes & Yes \\
\hline New York & & Yes & Yes & Yes \\
\hline \multicolumn{5}{|l|}{ North Carolina } \\
\hline \multicolumn{5}{|l|}{ North Dakota } \\
\hline Ohio & & & & Yes \\
\hline \multicolumn{5}{|l|}{ Oklahoma } \\
\hline Oregon & & Yes & & \\
\hline Pennsylvania & & Yes & Yes & Yes \\
\hline
\end{tabular}


Table 3 (continued)

\begin{tabular}{|c|c|c|c|c|}
\hline & $\begin{array}{l}\text { Food assistance } \\
\text { Qualified immi- } \\
\text { grants }\end{array}$ & $\begin{array}{l}\text { Cash assistance } \\
\text { Qualified immi- } \\
\text { grants }\end{array}$ & $\begin{array}{l}\text { Healthcare cover- } \\
\text { age } \\
\text { Qualified immi- } \\
\text { grants }\end{array}$ & $\begin{array}{l}\text { Healthcare coverage } \\
\text { Non-qualified } \\
\text { immigrants }\end{array}$ \\
\hline Rhode Island & & Yes & & Yes \\
\hline \multicolumn{5}{|l|}{ South Carolina } \\
\hline \multicolumn{5}{|l|}{ South Dakota } \\
\hline \multicolumn{5}{|l|}{ Tennessee } \\
\hline \multicolumn{5}{|l|}{ Texas } \\
\hline Utah & & Yes & & \\
\hline \multicolumn{5}{|l|}{ Vermont } \\
\hline Virginia & & & Yes & Yes \\
\hline Washington & Yes & Yes & Yes & Yes \\
\hline \multicolumn{5}{|l|}{ West Virginia } \\
\hline Wisconsin & Yes & Yes & & \\
\hline Wyoming & & Yes & & \\
\hline $\begin{array}{l}\text { Total number of } \\
\text { states }\end{array}$ & 7 & 22 & 15 & 17 \\
\hline
\end{tabular}

Source: Fortuny and Chaudry (2011), Tables 3, 4, pp 16-20

Qualified immigrants include LPRs, refugees and asylees, persons paroled into the United States for at least 1 year, persons granted withholding of deportation or removal, battered spouses and children, Cuban and Haitian entrants, and victims of severe human trafficking. Data are as of July 2010. 2. Nonqualified immigrants are foreign-born persons who do not fall under the qualified immigrant groups, including immigrants formerly considered permanently residing under color of law (PRUCOLs), persons with temporary protected status, asylum applicants, other lawfully present immigrants (such as students and tourists), and unauthorized immigrants. Data are as of July 2010

Non-qualified immigrants are foreign-born persons who do not fall under the qualified immigrant groups, including immigrants formerly considered permanently residing under color of law (PRUCOLs), persons with temporary protected status, asylum applicants, other lawfully present immigrants (such as students and tourists), and unauthorized immigrants. Data are as of July 2010

community health centers and $\$ 1.5$ billion for the National Health Service Corps for 5 years beginning in 2011 (Searles 2012: 145). In February 2018, Congress extended FQHC funding for another 2 years. Figure 1 describes the geographic distribution of FQHCs in 2011, using data from the Kaiser Family Foundation. Once again, we see significant concentrations in the top ten states with the largest foreign-born populations.

In 2010, President Obama signed the Patient Protection and Affordable Care Act (ACA) into law. It expanded healthcare coverage to approximately 32 million uninsured Americans and promised to reduce overall healthcare costs. Legal immigrants may receive ACA benefits from ACA through insurance exchanges and receive subsidies, but unauthorized immigrants are excluded and not allowed to do so (Warner 2012). Thus, recent healthcare reform has divided legal and illegal migrants and exacerbated inequalities between the two groups. Although the unauthorized always have the option of purchasing private insurance, the process 
Table 4 Healthcare coverage and FQHCs by state in 2012

\begin{tabular}{|c|c|c|c|c|c|}
\hline Location & Employer (\%) & Public (\%) & $\begin{array}{l}\text { Other pri- } \\
\text { vate }(\%)\end{array}$ & Uninsured (\%) & Total FQHCs \\
\hline United States & 48 & 31 & 5 & 15 & 1128 \\
\hline Alabama & 47 & 34 & 5 & 14 & 14 \\
\hline Alaska & 50 & 28 & 3 & 19 & 25 \\
\hline Arizona & 45 & 33 & 4 & 18 & 16 \\
\hline Arkansas & 40 & 38 & 4 & 18 & 12 \\
\hline California & 45 & 30 & 6 & 19 & 121 \\
\hline Colorado & 52 & 26 & 7 & 15 & 15 \\
\hline Connecticut & 58 & 29 & 5 & 8 & 13 \\
\hline Delaware & 51 & 35 & 4 & 10 & 3 \\
\hline District of Columbia & 49 & 36 & 7 & 8 & 4 \\
\hline Florida & 41 & 33 & 5 & 21 & 44 \\
\hline Georgia & 47 & 29 & 5 & 19 & 27 \\
\hline Hawaii & 53 & 35 & 4 & 8 & 14 \\
\hline Idaho & 47 & 29 & 7 & 16 & 11 \\
\hline Illinois & 50 & 31 & 5 & 14 & 37 \\
\hline Indiana & 52 & 32 & 3 & 13 & 19 \\
\hline Iowa & 53 & 30 & 7 & 10 & 13 \\
\hline Kansas & 50 & 31 & 6 & 13 & 13 \\
\hline Kentucky & 47 & 33 & 4 & 15 & 19 \\
\hline Louisiana & 43 & 34 & 3 & 20 & 24 \\
\hline Maine & 48 & 39 & 4 & 10 & 18 \\
\hline Maryland & 57 & 25 & 5 & 13 & 16 \\
\hline Massachusetts & 57 & 35 & 4 & 4 & 36 \\
\hline Michigan & 50 & 33 & 5 & 12 & 29 \\
\hline Minnesota & 57 & 28 & 6 & 9 & 15 \\
\hline Mississippi & 45 & 35 & 4 & 16 & 21 \\
\hline Missouri & 50 & 30 & 6 & 14 & 21 \\
\hline Montana & 41 & 33 & 8 & 18 & 15 \\
\hline Nebraska & 53 & 26 & 8 & 13 & 6 \\
\hline Nevada & 47 & 25 & 5 & 23 & - \\
\hline New Hampshire & 59 & 24 & 5 & 12 & 10 \\
\hline New Jersey & 55 & 26 & 4 & 15 & 20 \\
\hline New Mexico & 38 & 37 & 5 & 21 & 15 \\
\hline New York & 48 & 36 & 4 & 12 & 52 \\
\hline North Carolina & 46 & 32 & 5 & 17 & 28 \\
\hline North Dakota & 57 & 23 & 9 & 10 & 4 \\
\hline Ohio & 50 & 32 & 5 & 13 & 33 \\
\hline Oklahoma & 44 & 34 & 5 & 17 & 17 \\
\hline Oregon & 46 & 32 & 7 & 15 & 25 \\
\hline Pennsylvania & 52 & 31 & 6 & 11 & 35 \\
\hline Rhode Island & 50 & 33 & 5 & 12 & 8 \\
\hline South Carolina & 46 & 32 & 5 & 17 & 20 \\
\hline
\end{tabular}


Table 4 (continued)

\begin{tabular}{llllll}
\hline Location & Employer (\%) & Public (\%) & $\begin{array}{l}\text { Other pri- } \\
\text { vate }(\%)\end{array}$ & Uninsured (\%) & Total FQHCs \\
\hline South Dakota & 48 & 29 & 9 & 14 & 6 \\
Tennessee & 45 & 36 & 5 & 14 & 23 \\
Texas & 45 & 27 & 4 & 24 & 64 \\
Utah & 58 & 21 & 6 & 15 & 11 \\
Vermont & 47 & 40 & 5 & 8 & 8 \\
Virginia & 54 & 27 & 5 & 13 & 25 \\
Washington & 50 & 31 & 5 & 14 & 25 \\
West Virginia & 47 & 35 & 2 & 15 & 27 \\
Wisconsin & 52 & 32 & 6 & 10 & 16 \\
Wyoming & 51 & 26 & 6 & 17 & 5 \\
\hline
\end{tabular}

Sources: (1) Health Insurance Coverage of the Total Population, Henry J. Kaiser Family Foundation. Available at: http://kff.org/other/state-indicator/total-population/\#. (2) Number of Federally-Funded Federally Qualified Health Centers Available at: http://kff.org/other/state-indicator/total-fqhcs/

Notes: Italicized cells include the highest and lowest value for each column

\section{Number of Federally-Funded Federally Qualified Health Centers by State, 2011}

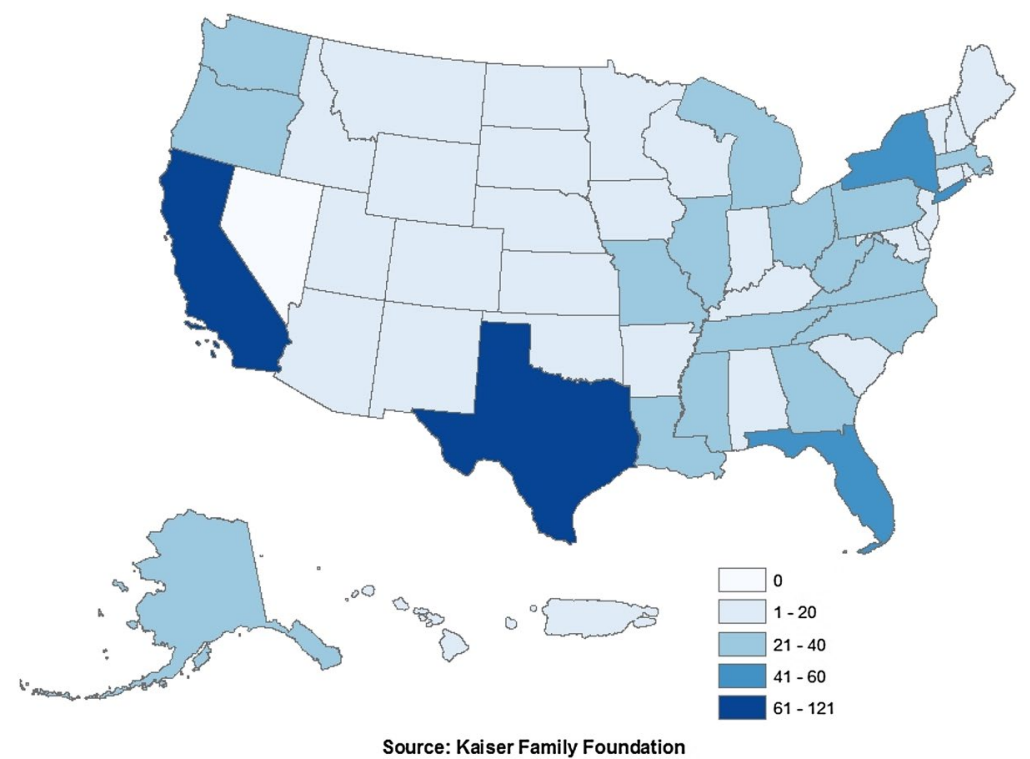

Fig. 1 Distribution of federally qualified health centers in 2011. Source: Kaiser Family Foundation. Raw data available at: http://kff.org/other/state-indicator/total-fqhes/ 
is very costly and requires identification using Social Security numbers, which most unauthorized do not have (Joseph and Marrow 2017).

\subsection{Immigration federalism: the role of state and localities}

In 1996, Congress passed the Illegal Immigration Reform and Immigrant Responsibility Act. This legislation contained a provision, e.g. 287(g), that permitted local enforcement agencies to cooperate with the Department of Homeland Security's Immigration and Customs Enforcement and report unauthorized immigrants for the purposes of deportation and removal of illegal aliens (Donato and Armenta 2011). As a result, 287(g) programs were set up in a variety of cities and states. Over time, they were replaced by the Secure Communities program. However, recent changes implemented by President Trump have reinvigorated the 287(g) program once again.

Recent studies document the increasing involvement of states and municipalities in the enforcement of US immigration policy (Provine and Varsanyi 2012; Donato and Rodriguez 2014; Amuedo-Dorantes et al. 2013; Armenta 2017). Much of this work emphasizes immigration federalism, i.e. the local devolution of enforcement authority, while also highlighting inherent contradictions (Newton 2012; Varsanyi et al. 2012; Ramakrishnan and Wong 2010; Armenta 2017) and revealing how localities have taken on the role of enforcing immigration law. Varsanyi et al. (2012: 139) characterized this new landscape as a "multilayered jurisdictional patchwork," which captures the "confusing, and often contradictory, geography of immigration enforcement in the United States". They show that overlapping and neighboring jurisdictions adopt contradicting practices towards immigrants, especially the unauthorized. At the same time, cooperation with federal authorities from local governments disrupts the tenuous relationship between local police and immigrant communities.

As a response to $287(\mathrm{~g})$ programs, states, cities, and some private institutions have adopted sanctuary policies that attempt to turn a blind eye to the presence of unauthorized migrants and refuse to cooperate with the federal government in apprehension or deportation activities related to the unauthorized. Currently, there are hundreds of cities across the country with this designation, including New York City, Los Angeles, Chicago, Philadelphia, San Diego and Miami. In addition to providing the unauthorized with safe haven, some sanctuary cities also extend social and health benefits, either by decoupling eligibility from legal status or by establishing these benefits program directly through state funding. Figure 2 provides an overview of states with and without state- or city-wide sanctuary laws in 2013. The pattern is broadly consistent: states with larger immigrant populations such as California and Texas are more likely to be in the sanctuary category than those with smaller populations.

\subsection{Public debate on healthcare access among immigrants}

On healthcare, one issue that has changed is how the presence of immigrants, both legal and unauthorized, are framed and perceived by the host society (Willen 2012). In particular, their deservingness is embedded in moral and ethical debates about 


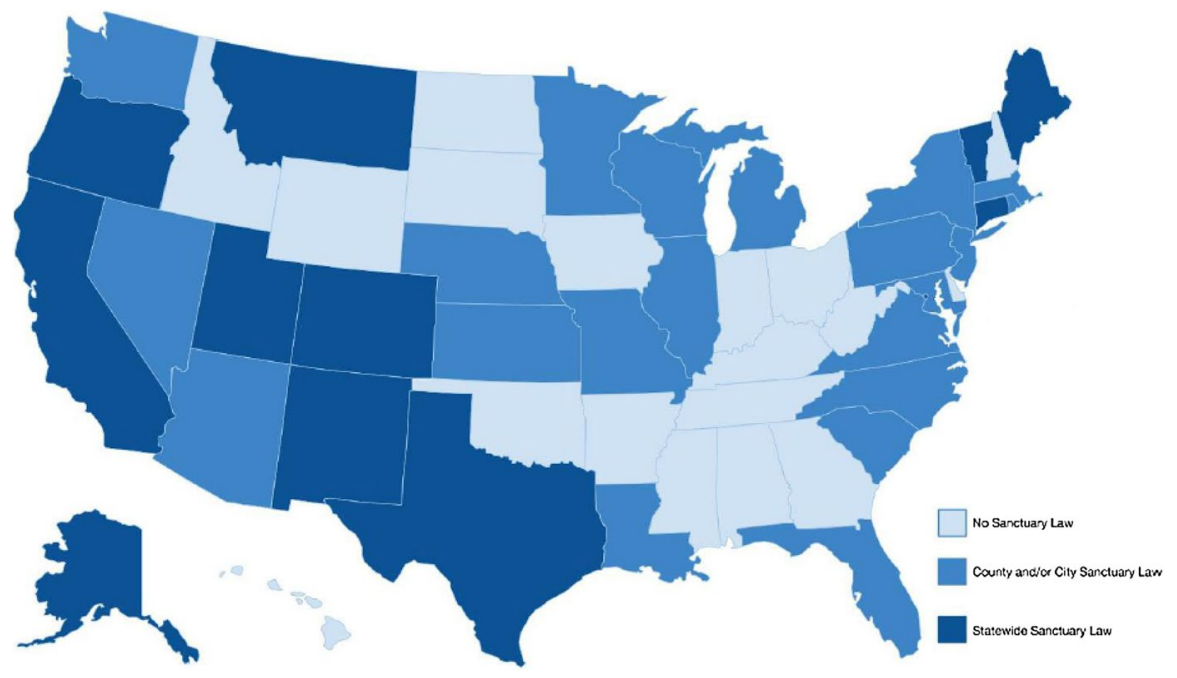

Fig. 2 Sanctuary policy by state in 2013. Source: Federation for American Immigration Reform (p. 2). Available at: http://www.fairus.org/DocServer/amnesty_2013_debate/Sanctuary_Policies_Across_the_ US_110513.pdf

the medical services to which the unauthorized are entitled. Analyzing the social science and public health discourse in the aftermath of PRWORA, Viladrich (2012) describes the competing frames about immigrants' access to health care benefits. Public health discourse consistently frames immigrants as deserving of healthcare because they contribute to US society in the form of hard work. For example, the "effortful immigrant frame" emphasizes the fact that immigrants underutilize medical services and account for lower levels of healthcare expenditures compared to natives (p. 824). The "cost-saving frame" further highlights unauthorized immigrants' potential mid- and long-term cost if their medical conditions are not given proper attention in the short run.

The "national security frame" draws on the perception that immigrants bring a disproportionate share of diseases and illnesses such as tuberculosis or HIV, which threaten the health of natives. After 9/11, this frame was pervasive and compounded with the occurrence of SARS. ${ }^{4}$ This was also used by public health professionals to justify providing healthcare access to immigrants because their well-being (both legal and unauthorized) was closely intertwined with US natives, hence "protecting them" was seen as an attempt to protect "us" (p. 825). For example, many physicians adopt this perspective in their work with immigrant patients, arguing that "immigrants do not constitute a separate population but an integral part of our communities. Neglecting their needs puts the whole society at risk" (Searles 2012: 136).

\footnotetext{
${ }^{4}$ SARs refers to severe acute respiratory syndrome, which is a viral respiratory disease. Between November 2002 and July 2003, southern China experienced an outbreak of SARS. During this period, there were more than 8000 cases and 700 fatalities reported in 37 countries.
} 
Finally, the "social justice frame" advocates for certain groups of vulnerable people, including refugees, pregnant women, children and the elderly, and often perceived to be deserving of healthcare as a human right (Viladrich 2012: 287). Viladrich (2012: 826) also documents the "chilling effect" or "voluntary withdrawal," when immigrants eligible for health and social benefits do not end up using them. One key reason might be immigrants" "internalized feeling of undeservingness" which resulted of the passage of welfare reform in 1996. Several studies suggest that welfare reform and immigration restrictions passed in 1996 created stress and confusion, resulting in many immigrants to voluntarily withdraw from using public services they were entitled to (Rodríguez and Hagan 2004; Hagan et al. 2008; Hagan et al. 2010).

\section{Healthcare access among the US unauthorized population}

Although the previous discussion focuses broadly on the US unauthorized population, our empirical analyses focus on Mexicans because they constitute a unique case study. First, Mexicans comprise the largest US immigrant group with a continuous history of migration more than a century. Second, despite a recent decline in Mexico-US migration after the 2008 economic recession, there has been tremendous growth in the population of immigrants from Mexico over the last four decades. From 1970 to 2010, the number of Mexican-born immigrants has increased from 760,000 to more than 12 million, representing the single largest sustained US immigrant flow from any country over the last half century. In 2010, one in ten Americans was of Mexican origin and they comprised about 30\% of the total foreign-born population. Third, Mexicans are also more likely than other groups to lack legal status, accounting for about $50 \%$ (or 5.6 million) of the total unauthorized population in 2016. Finally, we focus on Mexicans having been persuaded by Roberts (1997), whose comparison between Mexico-US migration and China's rural-urban migration suggests it is time to draw lessons from how legal status affects US healthcare access to that for rural-to-urban migrants in China.

The focus on legal status is important because it is associated with sociological, political, economic and health outcomes among immigrants. Legal status not only provides important access to resources and social provisions, but it also helps protect against poor mental health and psychological well-being. This section draws on data from the 2007 Hispanic Healthcare Survey (HHS) and the Mexican Migration Project (MMP) to describe healthcare coverage and utilization among Mexican immigrants. We begin by describing findings from the HHS, which has detailed information about legal status and include questions about access and utilization of healthcare services. The HHS sample was nationally representative of the US Latino population in 2007 and included significant numbers of recent immigrants and longestablished US-born citizens.

Figure 3 presents results on insurance coverage by legal status. As we would expect, both citizens and legal permanent residents are more likely than other groups to report having access to health insurance during the last 12 months. The rate of full coverage was $65.7 \%$ for US-born Mexicans, $63.9 \%$ for naturalized Mexicans, and $29.2 \%$ among temporary legal residents, compared to only $19.1 \%$ among the 


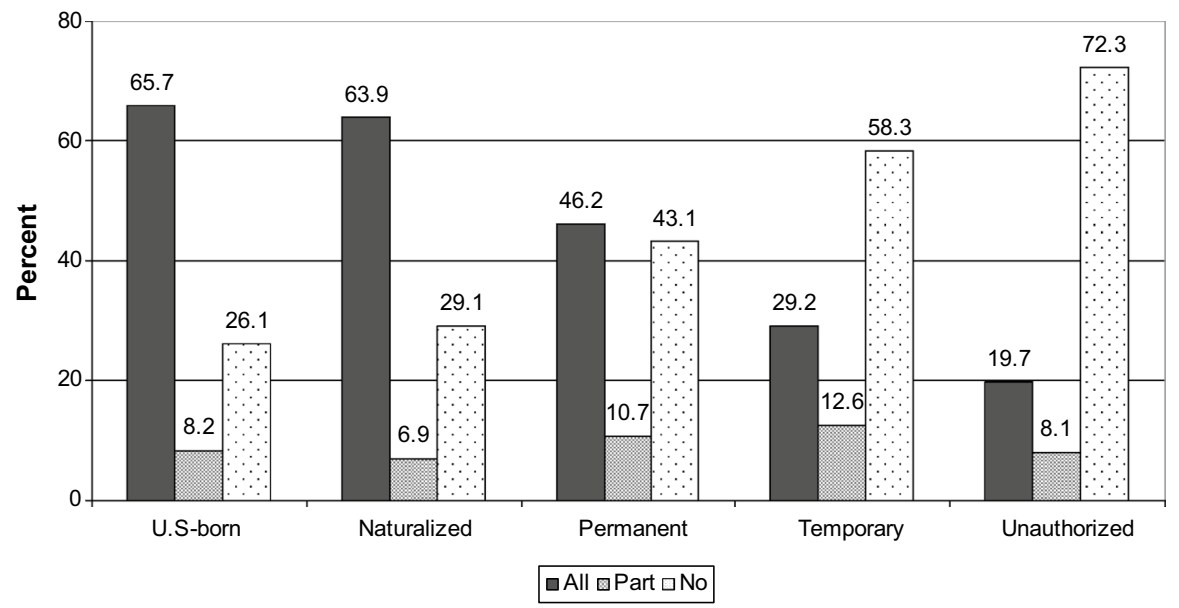

Fig. 3 Health insurance coverage by legal status among Mexicans in the US Source: 2007 Hispanic Healthcare Survey, Pew Hispanic Center, weighted results $(\mathrm{N}=2409)$

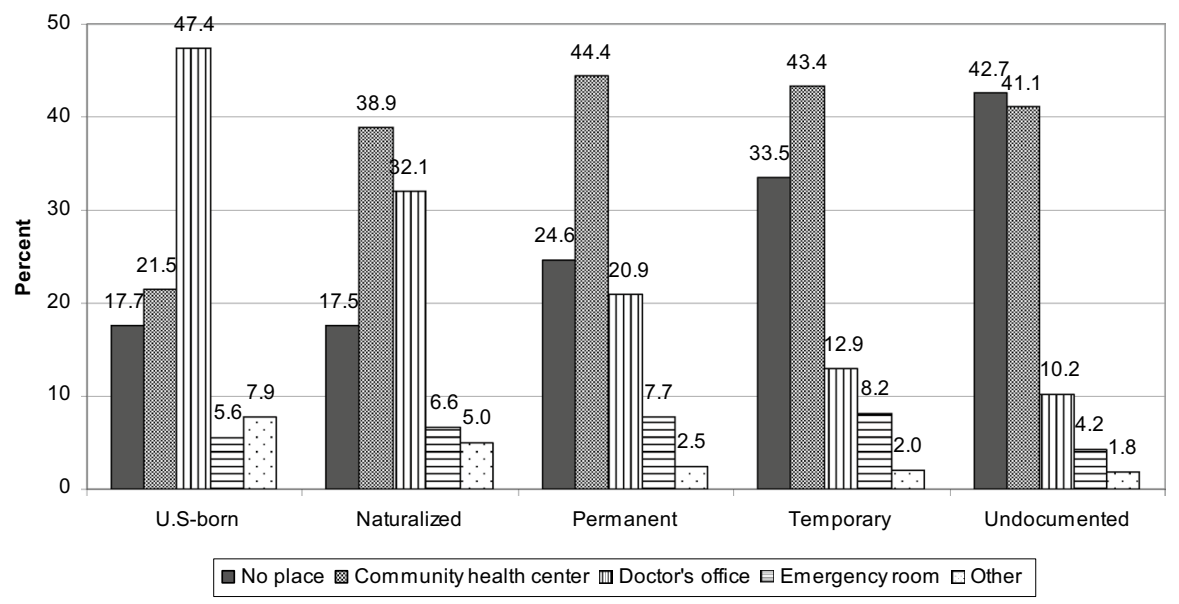

Fig. 4 Healthcare Utilization by Legal Status among Mexicans in the US. Source: 2007 Hispanic Healthcare Survey, Pew Hispanic Center, weighted results $(\mathrm{N}=2477)$. The "other" category includes "HMO", "some other place" and "doesn't go to one place"

unauthorized. In addition, only $26.1 \%$ among US-born Mexicans reported having no healthcare coverage, compared to $72.3 \%$ among the unauthorized.

By comparison, more than one-quarter of unauthorized immigrants reported having some coverage in the last 12 months, suggesting that lack of legal status does not entirely predict lack of coverage. There are three reasons for this. First, individuals may obtain health coverage via their spouse or parents, and this is especially the case among mixed status families. Second, states and localities vary in their level of coverage available for the unauthorized, especially pregnant women and children. 


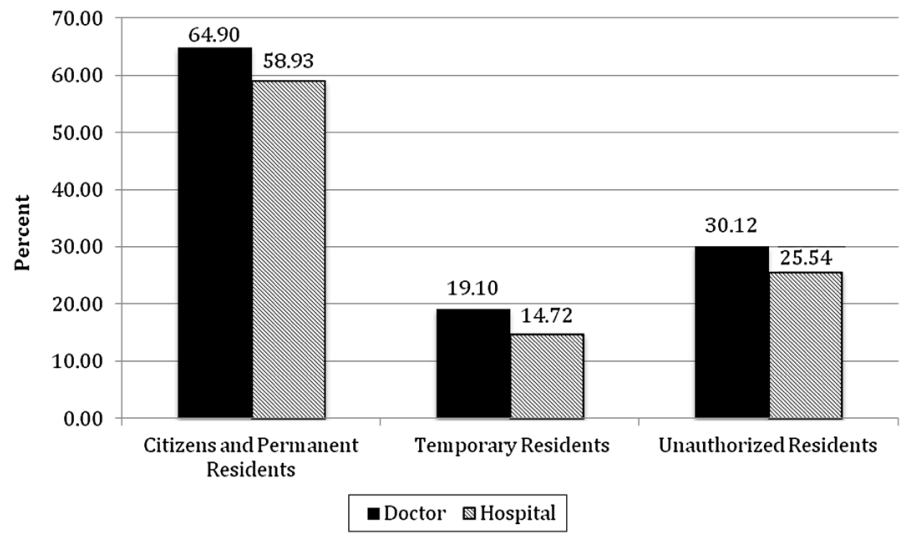

Fig. 5 Healthcare Utilization during Last US Trip by Legal Status. Source: Mexican Migration Project. The "unauthorized" category includes respondents who reported not having legal documents or having false documents on their most recent US trip, and those who entered as visitors/tourists but reported an US occupation

Third, anyone with some form of identification may purchase coverage from the private insurance market.

Figure 4 shows variations in the usual place to receive medical care by legal status. ${ }^{5}$ Community health centers and doctor's offices are the most common places of care, although there is a clear split by legal status. $47.4 \%$ of US-born Mexicans reported receiving care in a doctor's office, whereas Mexican immigrants were more likely to receive care at a health center, irrespective of legal status. This finding underscores the importance of community clinics and health centers for immigrants. In addition, $42.7 \%$ of the unauthorized reported having no place to go for routine care when they are sick or need advice about their health, compared to $17.7 \%$ among the US-born Mexicans. Figure 4 also shows that unauthorized immigrants reported the lowest levels of visiting doctor's office and using emergency services.

Another dataset with information on legal status is the Mexican Migration Project. Figure 5 provides results on healthcare utilization rate during the last US trip by legal status. Overall, citizens and permanent residents reported the highest rates whereas temporary residents reported the lowest rates of doctor visits and hospitalization. Among unauthorized migrants, 30.1\% reported having visited a doctor and $25.5 \%$ reported having been hospitalized. These rates are higher than those reported among Mexicans in the Hispanic Health Survey. Since the MMP interviews individuals who have returned to Mexico, these results suggest that the Mexicans in MMP may be more negatively selected on health compared to those in the HHS survey.

\footnotetext{
${ }^{5}$ For results based on a subsample of persons who reported "having a usual place for healthcare".
} 


\section{Toward a comparative agenda: implications for migrant health in urban China}

We outline here the rationale for a comparative research agenda about the impact of legal status on migrant health in the US and in China. We begin by describing the many similarities between Mexico-US migration and internal rural-to-urban migration in China. We then discuss the recent development of social provisions for rural migrants in urban settings in China and the implications for migrants' well-being. We then consider the lessons learned and implications of our US findings for our understanding of rural-to-urban migrants in China.

\subsection{Comparing Mexico-US migration to rural-urban migration in China}

Two decades ago, Roberts (1997) noted similarities between migrant flows from Mexico to the US and from rural to urban areas in China. While the history of Mexico-US migration is rather unique, many features of this migration flow are also applicable to rural-to-urban migrants in China. They include the 1954-miles US-Mexico border, the legacy of US recruitment of low-wage Mexican workers, and the large wage gaps between many sending communities in Mexico and many receiving areas in the US (Roberts 1997). Mexico-US migration has been cyclical, circular and seasonal for most of the last century (Massey et al. 2002). Migrants often came with the intention to work hard and accumulate some savings before returning to Mexico to improve life conditions back home. While the tightening of border control in the 1990s made return trips less likely because of higher reentry costs and unsafe Mexico-US crossing conditions, resulting in more permanent settlements across the US (Massey et al. 2002). However, the continuous influx of migrants from Mexico into the US has been ongoing for more than a century.

The analogies for rural-urban migration in China are striking. First, internal migration has generated high concentrations of rural migrants in urban areas. This so-called floating population numbers in the tens of millions in many urban areas. Second, rural-urban migration is predicted to intensify over the next decades as China undergoes economic development and urbanization. Third, rural-urban migration in China is often circular and, until recently, most rural migrants describe their initial migration as temporary. This temporary nature is reinforced by the strict hukou system which regulates and restricts movement and the rights of people who migrate. In fact, their lack of hukou status is an important factor that affects their urban experiences, making them quite similar to the US unauthorized population.

Over the last three decades, the urban population in China has increased from 191 million in 1980 to 622 million in 2009. Rural-to-urban migrants fueled this growth and they accounted for nearly $40 \%$ of the urban population (or approximately 260 million people) in 2010. In addition, another 200 million are projected to migrate to urban areas in this decade (Gong et al. 2012: 843-44). With nearly one-fifth of the Chinese population holding hukou (i.e. household registration) for locations other than where they live, the sheer size of the rural-to-urban migrant population in 
China makes it the largest migration flow in history in the world. At the same time, they face many risk factors and local barriers to accessing healthcare and achieving good health, including crowded living conditions, substandard housing, air pollution, occupational and traffic hazards, and changing diets and lifestyles in urban settings (Niu et al. 2011; Gong et al. 2012). Recently, official policies about migration have changed toward accepting and promoting migration as a key to economic growth. Although the hukou system do not control immigration, it still has a direct impact on access to important resources by making it difficult for migrants to regularize their status in other localities. Thus, it excludes migrants' eligibility for most state-based social provisions, such as educational opportunities for migrants' children and healthcare coverage for migrants (Fang et al. 2012). ${ }^{6}$ Aside from issues of eligibility, there are significant variations across localities and cities in the specific healthcare plans available to both migrants and non-migrants, reflecting the unique institutional arrangements and budgetary constraints of each locality (Niu and Zheng 2017). This heterogeneity at the local level is often lost in broader discussion of healthcare expansion in the Chinese context.

Specifically, healthcare plans vary in scope and quality on the details such as deductible amount, copayment rate, insurance cost and insurance responsibilities (i.e. employers-sponsored vs. migrants-initiated) (Niu and Zheng 2017). Another limitation for migrant workers in the current system is that they have to return to rural areas for healthcare. This often leads to delayed care, difficulties in the logistics of healthcare, and other problems. Although migrants contribute to urban governments, they receive few social services in return (Chen et al. 2010). In contrast, small cities and rural areas have fewer resources and collect fewer tax revenues because of significant out-migration of working-age populations. Yet, they are often responsible for return migrants who are often sicker than migrants who remain. Local governments can ensure that this population gets the care and delivery of services they need by establishing residence status by providing a housing lease or contract instead of hukou status or proof of temporary registration.

\subsection{The expansion of healthcare coverage in China and consequences for migrants' health}

Starting with the government's announcement of the expansion of healthcare coverage and its goal in achieving universal coverage by 2020, China has significantly expanded its insurance programs on both urban and rural fronts. Since the late 1990s and during the span of just one decade, China has achieved near universal healthcare coverage. Based on data from the 2003, 2008 and 2011 National Health Services Surveys, insurance coverage increased from just $9.7 \%$ in 2003, to $87.9 \%$ in 2008 and $95.7 \%$ in 2011 (Meng et al. 2012). At the same time, there is considerable variation in coverage; some cities such as Shanghai,

\footnotetext{
6 This is changing as cities grapple with the children of rural-to-urban migrants who make up a substantial portion of school-aged children and research has begun to focus on how the educational system affects migrant children with opportunities for upward mobility (Holdaway 2011).
} 
Table 5 Development of major health insurance programs in China (1988-present)

\begin{tabular}{lcl}
\hline Program description $^{\mathrm{a}}$ & Year $^{\mathrm{b}}$ & Proportion of Contribution towards plan $^{\mathrm{c}}$ \\
\hline $\begin{array}{l}\text { Public Service Health Insurance (PSHI) } \\
\text { Coverage for all public sector employees }\end{array}$ & 1988 & Government (100\%) \\
$\begin{array}{l}\text { Urban Employee Basic Medical Insurance (UEBMI) } \\
\text { Coverage for all urban employees }\end{array}$ & 1998 & Employer (80\%) and individuals (20\%) \\
$\begin{array}{l}\text { Urban Resident Basic Medical Insurance (URBMI) } \\
\begin{array}{l}\text { Coverage for urban residents, esp. students and } \\
\text { children }\end{array}\end{array}$ & 2007 & Government (50\%) and individuals (50\%) \\
$\begin{array}{l}\text { New Cooperative Medical System (NCMS) } \\
\text { Coverage for rural residents }\end{array}$ & 2003 & Government (67\%) and individuals (33\%) \\
$\begin{array}{l}\text { Medical Assistance Scheme (MAS) } \\
\text { Coverage for poorest 5\% of both rural and urban } \\
\text { migrants }\end{array}$ & 2003 & Government (primarily) \\
$\begin{array}{l}\text { Medical Insurance System for Migrant Employees } \\
\text { (MISM) }\end{array}$ & 2006 & Government (67\%) and individuals (33\%) \\
\begin{tabular}{l} 
Coverage for urban migrants \\
\hline
\end{tabular}
\end{tabular}

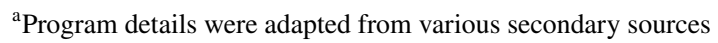

b"Year" denotes the year when the program started

${ }^{\mathrm{c}}$ Figures for the proportion of contribution made towards the plan were approximately based on the program guidelines. These figures have fluctuated over the years as the program evolves over time, with the government making a higher proportion of the contribution than it used to. Government contribution can come from both the central and local level

${ }^{\mathrm{d}}$ This was formerly known as the Cooperative Healthcare Service System for Migrant Workers (CHSMW). The program began in 2005 and evolved into the current MISM program

Shantou, and Xiamen report near $100 \%$ coverage, whereas rates in Beijing and Zhuhai are much lower (Lam and Johnston 2012: 10). While access is almost universal in some places, healthcare remains rather expensive and its quality varies significantly across localities (Eggleston 2010). One key attribute of China's healthcare system is that although primary care coverage is almost universal, it relies heavily on out-of-pocket payments for advanced and/or specialized procedures. Because these procedures are often very costly, migrants are very likely to find them unaffordable.

In general, the Chinese population is covered by six major health insurance programs as public-sector employees, urban workers, other urban residents, rural residents, poor residents, and urban migrants. Public sector workers are covered under "Public Service Health Insurance," which began in 1988 and provides full coverage for about $5 \%$ of the total population. Urban residents receive the "Urban Employee Basic Medical Insurance (UEBMI)," which began in 1998 and covers about $28 \%$ of the total urban population. Urban residents, such as students and children, not insured by the UEBMI scheme, are covered under the 2007 Urban Resident Basic Medical Insurance (URBMI). Rural residents receive coverage through the New Cooperative Medical System (NCMS) which started in 2003. 
This healthcare scheme covered 720 million agricultural households in 2007, after just four years of implementation. Finally, the poorest individuals are covered under the "Medical Assistance (MA) Scheme” which received $¥ 800$ billion additional funding per year for three years in 2009. Recently, some localities have also launched the "Medical Insurance System for Migrant Employees" (MISM) to target urban migrants, but compliance levels have been low due to barriers that are discussed below (Lam and Johnston 2012). Table 5 presents the main features of these programs.

As the different health schemes illustrate, responsibility for financing and administering healthcare has also become decentralized in China. This is analogous to the decoupling between US immigration mandates and the implementation of healthcare provisions at the state and local areas. For example, provincial, county and city governments in China fund healthcare schemes and administer eligibility, but this can lead to greater inequities because larger cities are more likely to draw from larger tax revenues and hence can afford more. Although the healthcare system is managed at the local level, none of the current urban plans includes coverage for migrant workers. Since migrant workers continue to be excluded from gaining an urban hukou, despite reforms, they are more likely to be excluded from access and in a vulnerable position.

With respect to health, studies have found that migrants consistently underutilize health services, leading to delayed care and further health problems (Hong et al. 2006; Mou et al. 2009; Hesketh et al. 2008). For example, a study of migrant workers in Shenzhen, a main destination for Chinese migrant workers, showed that $55.1 \%$ of migrant workers were uninsured and $62.1 \%$ of migrant workers who reported illness did not visit a doctor (Mou et al. 2009). Another major survey in Zhejiang Province documented large differences in health insurance coverage, with $58 \%$ of urban residents having coverage compared to only $19 \%$ of urban migrants and $9.5 \%$ of rural residents (Hesketh et al. 2008). The study documented the "healthy migrant effect" with migrants reporting the best self-rated health and reported the least acute illness, chronic disease, and disability, after controlling for age and education, despite their poor living conditions and inattention to health.

These barriers are similar to those facing the US unauthorized population. Hong et al. (2006) interviewed 90 migrants in Beijing and Nanjing and found that in addition to the lack of insurance coverage, most migrants reported spending very little money on healthcare, except in the case of accidents or injuries where medical care was immediately required. Most reported low utilization rates of medical facilities. Reasons for lack of service usage include the high cost of medical care, lack of time, perception that hospital usage is a luxury that they simply cannot afford, and fear that if they are perceived as unhealthy, they might also be expendable from work (taking a day off to see a doctor is often unaffordable due to the lack of pay). Therefore, migrants seek other options to cope with their illness by adopting self-treatment with over-the-counter medicine, delaying necessary care, and receiving care in smaller (and often unlicensed) clinics. Because the main issue is affordability, many expressed a preference for community centers vs. private clinics whereas hospitals are seen as the last resort and a luxury (Lam and Johnston 2012). 


\section{Lessons from the US experience and implications for migrant health in urban China}

This comparison provides new insights for understanding rural-urban migration in China. The US migration flow has matured over time (Roberts 1997) whereas the Chinese rural-urban migration shows no signs of abatement. Therefore, the US experience in immigration control and integration might offer helpful lessons when thinking about how to integrate the migrant population in urban China. For example, the stigmatization and marginalization of the US unauthorized population has led some scholars to speculate about their permanent racialization and confinement to the underclass (Massey et al. 2002). Researchers have also documented the psychological and emotional costs of being unauthorized in the US (Aranda et al. 2014) and the significant social costs of family separation, especially among migrant parents in the US and their children that were left behind in Mexico (Dreby 2010; Abrego 2013). By the same token, migrants in China report significant experiences of stigmatization and discrimination in urban contexts, along with social isolation, harsh working conditions, and few legal protections. As a result, improving the integration of migrants into urban settings will improve overall migrant health and well-being, thereby reducing social costs and alleviating the disproportionate healthcare burden faced by sending communities.

The US has experienced the growth and spread of new immigrant destinations, which are disproportionately comprised of Latino and unauthorized populations. However, the increase in border control illustrates one unintended consequence of immigration policy: the emergence of a large permanent settlement of unauthorized immigrants, marking a fundamental shift away from circular Mexico-US migration in prior decades. Thus, the US experience suggests that immigration policies can and do exert effects on migrant flows. Given the enormous size of current and projected migrant flow in China, it is important that the central government monitors this population flow because recent evidence suggests migrants are increasingly settling down permanently in urban China and not "floating" any more (Connelly et al. 2011). If this is true, then successful migrant integration policy is an extremely important issue.

The social provision of healthcare services to US immigrants carries implications for understanding the link between hukou status and healthcare access in urban China. As China's megacities grapple with ongoing migration between rural and urban settings, how hukou status will continue to matter for access is a potentially important question that directly affects health and well-being. At a broader level, it raises questions of how Chinese cities are incorporating urban migrants and their children. What we have learned here is that unauthorized status means less access to healthcare and worsens health outcomes. Unauthorized migrants disproportionately rely on services provided by healthcare centers and community clinics in the US, a finding that is also echoed in China among rural-urban migrants. Rethinking the role of community clinics as a social safety net will go a long way toward providing basic healthcare coverage for migrants. If the US experience is a guide, there are many barriers to healthcare access for the 
unauthorized. Therefore, proactively reaching migrants and providing information about services available to them will further reduce barriers to access.

Another lesson learned from the United States is that legal status is better understood as a continuum, not a dichotomy. Although immigration debates often draw a bright line between the authorized and the unauthorized, legal status is much more complex. US immigrant households are increasingly mixed-status, where one or more family members have citizenship by birth but others are unauthorized. By comparison, the legal-illegal distinction makes even less sense in the Chinese case, as migrants and non-migrants in urban contexts are both legal citizens of the country but entitled to different types of services and have different legal rights based on hukou status and other residence requirements. For example, China's laws require rural-to-urban migrants without an urban hukou to acquire a temporary residency registration from the local government. However, the registration process is cumbersome and expensive, requiring "the submission of 12 fees to local government and up to six governmental restrictions or permits for employment" (Li et al. 2006: 8). The entire process takes at least 3 months and costs between 500 and 1000 Yuan, which is the equivalent of about 1 month's salary for most urban migrants. As a result, most either do not meet the requirements for registration or simply fail to register. These unregistered migrants are deemed as illegal and subject to discrimination and stigmatization. The US experience suggests that changing registration law, reducing fees and simplifying the procedures would help facilitate the registration and management of migrants. It will also help reduce the floating populations in cities and provide them with basic protection.

The local devolution of enforcement authority in recent US immigration policy has important consequences for the social provision of healthcare. Given the increasingly restrictive nature of benefits and generally hostile environment toward unauthorized immigrants since 2016, local municipalities have taken on increasingly important roles by distinguishing the eligibility criteria of the authorized vs. unauthorized. In China, the rapid expansion of healthcare reform toward universal coverage has also become increasingly decentralized, with local governments now in charge of providing access and contributing to program costs. One consequence may be the emergence of greater inequality in access across cities and regions, as some may have more resources to devote to migrants than others. Localities that receive a disproportionate share of migrants such as Beijing, Shanghai and Shenzhen, and cities that have not had prior experiences with migration, would have to grapple with the task of providing migrants with basic social services. The US experience shows significant autonomy at the state and local level. By the same token, comparative questions about how different localities deal with migrant presence will improve our understanding of the institutional and policy context that shapes health outcomes.

Investigating these topics in a comparative context is both important and timely given the reform and expansion that has occurred in China's healthcare system. Whereas only a fraction of the population was covered under some form of health insurance just a decade ago, most of the Chinese population is now covered under various plans that have emerged both in rural and urban contexts. At the same time, issues of affordability and availability, along with care quality, continue to persist. Furthermore, disparities among urban and rural areas remain and urban migrants 
continue to be left out of much of the healthcare system and prevented access to the full range of services. Attention to these patterns of inequalities will improve the well-being of migrants and contribute to their integration in the ever-changing Chinese urban landscape.

In this paper, we document the changing migrant healthcare policy landscapes in China and the US. We recognize that our efforts remain incomplete given the shifting policy priorities in both countries over the last few years that might lead to new divergences in the two cases. In the US, the election of Donald Trump as president in 2016 has further fueled anti-immigrant sentiments with increasing threats of deportation for the unauthorized population including beneficiaries of the Deferred Action for Childhood Arrivals (DACA) program. As this article goes to press, efforts to repeal the ACA are under way and, if successful, they may further impact healthcare access for unauthorized migrants who have heavily relied on FQHCs for healthcare. In China, the central government recently announced a 5-year plan (2015-2020) for healthcare reform that seeks to build on and expand coverage by deepening access and reducing costs. While the expansion of healthcare coverage in China has been remarkable over the last decade, large out-of-pocket medical expenses remain a challenge, even among those with health insurance. A related question is whether health insurance will be locally and nationally funded as healthcare coverage expands. This may either deepen or reduce existing rural-urban inequalities in healthcare access, especially among rural-to-urban migrants. Looking ahead, healthcare access for US unauthorized migrants is likely to become more restrictive whereas healthcare provisions for rural-to-urban migrants in China is likely to be more inclusive. This potential divergence further highlights the value of a comparative approach to the study of healthcare provisions more specifically and social policies more broadly in both nations.

\section{References}

Abrego, L. (2013). Sacrificing Families: Navigating Laws, Labor, and Love Across Borders. CA: Stanford University Press.

Amuedo-Dorantes, C., Puttitanun, T., \& Martinez-Donate, A. P. (2013). How do tougher immigration measures affect unauthorized immigrants? Demography, 50(3), 1067-1091.

Aranda, E., Menjivar, C., \& Donato, K. M. (2014). The spillover consequences of an enforcement-first US immigration regime. American Behavioral Scientist, 58(13), 1687-1695.

Armenta, A. (2017). Protect, serve, and deport: The rise of policing as immigration enforcement. Berkeley, CA: University of California.

Chen, C., Henry L., Gerald, B., \& Ding, S. (2010). Internal migration and 'rural/urban' households in china: implications for health care. In Paper presented at the ten years of war against poverty conference, Chronic Poverty Research Center.

Connelly, R., Roberts, K., \& Zheng, Z. (2011). The settlement of rural migrants in urban China-Some of China's migrants are not 'floating' anymore. Journal of Chinese Economic and Business Studies, 9(3), 283-300.

Donato, K. M., \& Armenta, A. (2011). What we know about unauthorized migration. Annual Review of Sociology, 37, 529-543.

Donato, K. M., \& Rodriguez, L. (2014). Police arrests in a time of uncertainty: The impact of 287(g) on arrests in a new immigrant gateway. American Behavioral Scientist, 58(13), 1696-1722.

Dreby, J. (2010). Divided by Borders: Mexican Migrants and their Children. Berkeley: University of California Press. 
Eggleston, K. (2010). 'Kan Bing Nan, Kan Bing Gui': Challenges for China's healthcare system thirty years into reform. In J. C. Oi, S. Rozelle, \& X. Zhou (Eds.), Growing pains: Tensions and opportunities in China's transformation. Stanford, CA: Walter H. Shorenstein Asia-Pacific Research Center.

Fang, K., Shia, B., \& Ma, S. (2012). Health insurance coverage and impact: A survey in three cities in China. PLoS One, 7(6), e39157.

Fortuny, K., \& Chaudry, A. (2011). A comprehensive review of immigrant access to health and human services. Washington, D.C.: The Urban Institute, April.

Goldman, D. P., Smith, J. P., \& Sood, N. (2005). Legal Status and Health Insurance among Immigrants. Health Affairs, 24(6), 1640-1653.

Gong, P., Liang, S., Carlton, E. J., Jiang, Q., Jianyong, W., Wang, L., et al. (2012). Urbanisation and health in China. Lancet, 379, 843-852.

Hagan, J., Brianna, C., \& Rodriguez, N. (2010). The effects of US deportation policies on immigrant families and communities: Cross-border perspectives. North Carolina Law Review, 88, 1799-1823.

Hagan, J., Eschbach, K., \& Rodriguez, N. (2008). US deportation policy, family separation, and circular migration. International Migration Review, 42, 64-88.

Hartman, M., et al. (2010). Health spending growth at historic low in 2008. Health Affairs, 29(1), $147-155$.

Hesketh, T., Jun, Y. X., Li, L., \& Mei, W. H. (2008). Health status and access to health care of migrant workers in China. Public Health Reports, 123(2), 189-197.

Holdaway, J. (2011). A common challenge: demographic transition, social stratification and the education of the children of immigrants in China, Europe and the United States. In Paper presented at the CASS-SSRC international conference, labor migration and the integration of new and second generation, held in Beijing, August 24-25, 2010.

Hong, Y., Li, X., Stanton, B., Lin, D., Fang, X., Rong, M., et al. (2006). Too costly to be ill: Access to health care and health seeking behaviors among rural-to-urban migrants in China. World Health and Population, 5(1), 19-31.

Hopkins, D. J. (2010). Politicized places: Explaining where and when immigrants provoke local opposition. The American Political Science Review, 104(1), 40-60.

Joseph, T. D., \& Marrow, H. B. (2017). Introduction to the special issue: Lessons from the affordable care act for the health of immigrants and minorities in the United States. Journal of Ethnic and Migration Studies, 43(12), 1965-1984.

Krogstad, J. M., Passel, J. S., \& Cohn, D. (2017). Five facts about illegal immigration in the US. Pew Research Center Report. Access on 2 Mar 2018.

Lam, K. K. F., \& Johnston, J. M. (2012). Health insurance and healthcare utilisation for Shenzhen residents: A tale of registrants and migrants? BMC Public Health, 12, 868.

Li, X., Stanton, B., Fang, X., \& Lin, D. (2006). Social stigmatization and mental health among rural-tourban migrants in China: A conceptual model and some future research needs. World Health and Population, 8(3), 14-31.

Marrow, H. B. (2012). Deserving to a point: Unauthorized immigrants in San Francisco's universal access healthcare model. Social Science and Medicine, 74(6), 846-854.

Massey, D. S., Durand, J., \& Malone, N. J. (2002). Smoke and mirrors: Mexican immigration in an era of economic integration. New York: Russell Sage Foundation.

Meng, Q., Ling, X., Zhang, Y., Qian, J., Cai, M., Xin, Y., et al. (2012). Trends in access to health services and financial protection in China between 2003 and 2011: A cross-sectional study. Lancet, 379, 805-814.

Mou, J., Cheng, J., Zhang, D., Jiang, H., Lin, L., \& Griffiths, S. M. (2009). Health care utilisation amongst shenzhen migrant workers: Does being insured make a difference? BMC Health Service Research, 9, 214.

Newton, L. (2012). Policy innovation or vertical integration? A view of immigration federalism from the states. Law and Policy, 34(2), 113-137.

Niu, J., \& Zheng, Z. (2017). Hukou-restricted migration and migrant's health: Evidence and policy implication. China Population and Development Studies, 1(2), 81-103.

Niu, J., Zheng, Z., Zhang, L., \& Zeng, X. (2011). Labor migrants' working and living environments and the related health impacts: Evidence from Shenzhen. Population Research, 3, 64-75. (in Chinese).

Passel, J. S., \& Cohn, D. (2011). Unauthorized immigrant population: National and state trends, 2010. Washington, DC: Pew Hispanic Center, February.

Portes, A., Fernández-Kelly, P., \& Light, D. (2012). Life on the edge: Immigrants confront the american health system. Ethnic and Racial Studies, 35(1), 3-22. 
Provine, D. M., \& Varsanyi, M. W. (2012). Scaled down: perspectives on state and local creation and enforcement of immigration law. Introduction to the special issue of law \& policy. Law and Policy, 34(2), 105-112.

Roberts, K. (1997). China's 'tidal wave' of migrant labor: What can we learn from Mexican undocumented migration to the United States? International Migration Review, 31(2), 249-293.

Rodríguez, N., \& Hagan, J. (2004). Fractured Families and Communities: Effects of Immigration Reform in Texas, Mexico and El Salvador. Journal of Latino Studies, 2(3), 328-351.

Searles, C. (2012). Beyond health care reform: Immigrants and the future of medicine. Ethnic and Racial Studies, 35(1), 135-149.

US Bureau of Primary Care. (2008). Health centers: America's primary care safety net. Rockville, MD: US Bureau of Primary Care.

Varsanyi, M. W., Lewis, P. G., Provine, D. M., \& Decker, S. (2012). A multilayered jurisdictional patchwork: Immigration federalism in the United States. Law and Policy, 34(2), 138-158.

Viladrich, A. (2012). Beyond welfare reform: Reframing undocumented immigrants' entitlement to health care in the United States, a critical review. Social Science and Medicine, 74(6), 822-829.

Warner, D. C. (2012). Access to health services for immigrants in the USA: From the great society to the 2010 health reform act and after. Ethnic and Racial Studies, 35(1), 40-55.

Willen, S. S. (2012). Migration, "Illegality," and Health: Mapping Embodied Vulnerability and Debating Health-Related Deservingness. Social Science and Medicine, 74(6), 805-811.
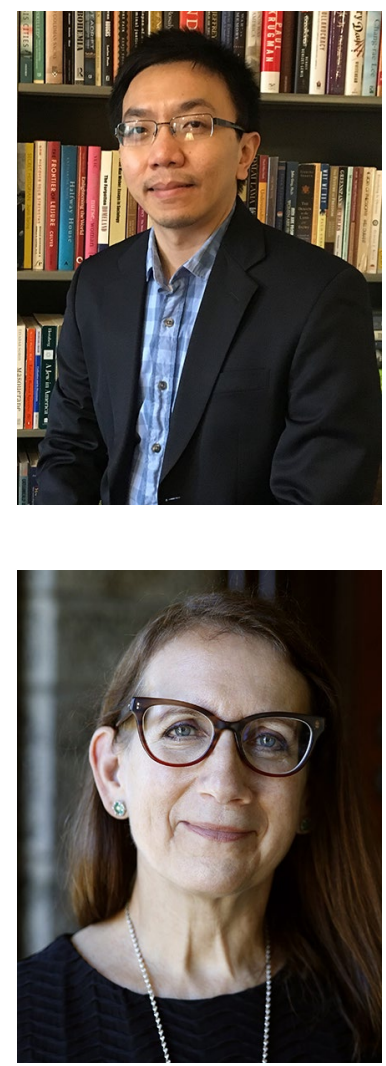

Van C. Tran is Assistant Professor of Sociology at Columbia University.

Katharine M. Donato is Donald G. Herzberg Professor of International Migration in the School of Foreign Service at Georgetown University. 